\title{
Subsidiary Sources of Funds to Minimise Financial Constraints on School Budget in Kenya
}

\author{
Neneh Nderitu \\ School of Education, Mount Kenya University \\ chemichemis2012@rocketmail.com \\ Alice Wambui Ngunju \\ School of Education, Mount Kenya University
}

\section{Doi:10.5901/mjss.2014.v5n5p}

\begin{abstract}
Although various studies have been conducted on special education needs, few researchers have narrowed down to focussing on specific categories of these institutions, particularly the secondary schools for the Hearing impaired. Rev. Muhoro School for the deaf has a unique feature over the other two secondary schools for the deaf, Kuja School for the deaf and the Mumias Girls for the deaf, in that it is an integrated institution. Most of the Hearing Impaired students rely heavily on sponsors and Government school budget allocations. These at times fail to release the funds on time, leaving the school crippled. It is thus evident that the government and household income alone cannot squarely and adequately meet the entire financial needs for the National education sector. This factor and other related predicaments has prompted the researcher to address the situation of subsidiary finances in special education and hence the statement of the problem that 'subsidiary sources of funds to minimise financial constraint on school budget in Rev. Muhoro School for the deaf in Nyeri, district'. The study used a case study design because of the number of such schools and the distance connecting them. The selected locale was more representative than any other secondary school for the hearing impaired students. The study has focussed on; finding out how the institution is financed, examined whether the finances available are able to meet the running of the institution, examined the challenges encountered by the administration on the planning of the allocated finances in the institution, explored on alternative ways of earning extra finances so as to ensure smooth and uninterrupted learning of these institutions.
\end{abstract}

Keywords: Education, Schools, Finances, Performance, Management

\section{Background}

Educational planning is a far broader activity than model building. The purpose of educational planning is to advance educational improvement, whether they are quantitative, as rapidly as possible and as cheaply as possible, to benefit individuals and the nation. Education is now universally recognized as a form of investment in human being, which yield economic benefits and contribute to a country's future wealth by increasing the production of its people. Thus, expenditure on education can be partly justified in terms of the potential contribution of education to economic growth. According to Beckley (1985), the question of educational opportunity for every individual is one that continues to be problematic in the quantitative and qualitative terms. In spite of increasing enrolment rate, and high priority accorded to education by the Government, the percentage of children benefiting from education provision both in primary and secondary level continued to be very low.

Since the introduction of policy of cost sharing as depicted in sessional paper No. 1 of 1996 on "Economic Management for Renewed growth," and sessional paper No. 6 of 1988 on "Educational and Manpower training for the next decade and beyond," access to education has been affected. This burden has ushered total effort from parents toward meeting the cost of education for their children in form of school levies and other expenses. This situation has made schooling out of reach for a significant number of students. According to Kibbogy S.J. (2001), an increasing number of students have continued to drop out of school before completing the full education cycle, a situation consisting a serious drain and wastage on the country's budget. Ideally, the number of students who enrol at the beginning of each year one should be the number who complete form 4, four years later, and should be absorbed in colleges, vocational school, technical institutions or universities. This would be in line with the curriculum set up and its expectations; with 8-44 system adopted in Kenya implying 8 years in primary school, 4 years in secondary school and 4 years in universities 
(ROK, 1996).

There is need to arrest the situation on dropouts so as to be in line with the educational requirements of Ministry of Education as stated in the goals and objectives of education. This would show commitment to comply with the requirements or philosophy of convention on rights of the child on provision of basic education for all children. (UNICEF 1994). In spite of all the efforts exerted in the expansion of education in Kenya, problems are still inherent in the education sector. Dropout rates in schools are still high, and access to schools is proving difficult. The main reason cited for this decline is the private cost for schooling. Although many children would like to go to school and their parents would like to send them to school, most low and middle-income groups are not able to do so. Secondary school fees constitute a very high proportion of household income (Reolikar, 1999).

Education is a powerful instrument for reducing poverty and inequality, improving health and social wellbeing, and laying the bases for a sustainable economic growth. It is a crucial tool for building democratic societies and dynamic globally competitive economies (World Bank 2002:8). This perhaps serves to explain why education, the world over, is given priority by governments and individuals, often willing to spend colossal amount of money in its acquisition.

Throughout the world, children who have disabilities have been traditionally marginalised within or excluded from school (Ainscow and Memmenasha 1998:111). Children with hearing impairment are found globally hence the need for their appropriate educational placement. It is evident that children with disabilities worldwide have received education in segregated institutions like special boarding schools, special units, small homes or orphanages. Definition given to special education has actually locked out a hearing impaired child, since the objective of special education overlook the fact that disability is not inability. A hearing impaired person can excel well academically hence the need to finance their education more than ever before. The impact of cost- sharing policy on education did not spare the hearing impaired schools. Professor George Saitoti observed that, the crisis resulting from the implementation of structural adjustment programmes (SAPS) initiated by the Breton woods institutions would have profound effect on education. This actually did happen, and did not segregate the hearing impaired institutions. The policy (Structural Adjustment Programmes) became counter-productive for primary education, as it lowered gross enrolment rates from $105 \%$ in 1989 to $88 \%$ in 1998 (Republic of Kenya 1999: 252).

The policy also increased inequalities as regions with "nothing to share" was unable to contribute to educational development (Republic of Kenya 1999:258). The National development plan 2002-2008 (Republic of Kenya 2002: VI) notes that poverty incidence increased from $52 \%$ in 1997 to $56 \%$ in 2000. Mills (2003) observed that primary and secondary school gross enrolment rate dropped significantly through the 1990s largely due to the increasing cost of education to parents. It is now clear that the previous cost being charged to parents were the biggest constraints on many children attending school. The government must address and resolve the issue of cost and financing arrangement which have led to the deterioration of education at all levels.

This policy did not spare any special institution as its implementation was across the board. The master plan on education and training (M.P.E.T) 1997-2000 came to the conclusion that the policy of cost-sharing has been a contributory factor to falling enrolments as well as failing schools. This posed a critical problem to the government which had to contain the cost of the system within the education kitty and at the same time reduce the burden on the parents and guardians. Muya (1989) argues that while cost sharing is a convenient way of shedding the bloated education budget for the exchequer, it led to social inequality and far reaching implications on the education accessibility.

Karugu et al (1995:1) noted that the education of the vulnerable groups such as the handicapped and children in special difficult circumstances was singled out at the world summit for children (New York, 1990) as an area that requires special attention by the government. The education declaration (Jomtien Thailand, 1990) emphasized the right of children to education as an empowerment tool. Being a signatory, Kenya has a commitment to ensure access, equitability and quality of special education programmes for those disadvantaged groups. Every child is entitled to free basic education which is compulsory in accordance with article 28 of the United Nation Convention on the rights of the child. Children with disabilities must be treated with respect. They should be given the medical care they require and education training free of charge or at a reduced cost where possible (The children act No. 8 of 2001: 1-3). This clause should be extended to include those who are in secondary schools.

The high cost of education to the parents has been a major cause of low enrolment, retention and participation rates in education sector. According to the second report on poverty in Kenya (VOL. II,MOF\&P), 30.7\% of the children out of school cited affordability as the main reason for their non-attendance (ROK 2003 (c)) generally the escalating cost of education have had negative impact on access, equity and quality. According to Fordham (2002), learning materials are the key ingredients for learning. World Bank (1988) observed that lack of these resources has affected the quality of education. Unless the instructional materials reach the classroom, they cannot be effective, and unless they reach all classrooms they cannot promote equitable learning opportunities (Inter- Agency Commission, 1990). 
The first draft of the education bill by MOEST dated Dec, 2002 in relation to special education proposes that; The minister shall provide equal opportunities for all learners with special education in the mainstream and in special school and shall provide and keep under review adequate arrangement aids and services including resources that would in appropriate cases support the provision of free education and training for learners with special education needs. Any person who denies or prevents any child who is in need of special education from receiving or gaining access to such education, commits an offence and is liable to a fine of one hundred thousand shillings or six months imprisonment (Education Bill, First Draft 2002: 6-7).

In the Kenya we live today there are so many hearing impaired children shut out of the school system because of lack of fees. Either because their parents are in abject poverty or their sponsors have withdrawn. A lasting solution should be arrived at with speed so as to reduce the high wastage rate. Since these children performs and compete favourably with the others, given the same educational curriculum, then a conducive academic environment should be made available.

The nations of the world speaking through declaration of human right (United Nation General Assembly 1948, Article 26) stated that everyone has a right to education and that education shall be free at least in the elementary and fundamental stages with elementary education being compulsory. Virtually all newly independent countries in pursuit of economic development and social justice gave education, particularly primary education top priority (Lockheed and Verspoor et al 1991:22). This may have been in the realization that education is a key determinant of earnings and therefore an important exit route for poverty (Republic of Kenya 2003:39). This to the view of the researcher should apply to all human beings regardless of their physical, mental, emotional status except and unless the problem is very severe and profound because nobody would enjoy being dependent on others. At the current rates of education expansion, it is projected that by 2015, more than 100 million school- aged children will still not be in primary school (World bank 2002:3). Relying on a commonly used parameter that the prevalence rate for impairment is $6 \%-7 \%$ of the total population (Republic of Kenya 1998:26) then an approximate 7 million school-aged children with special education needs will still be out of school by 2015. And if we were to take an arbitrary figure (say 2\%) to represent the hearing impaired children, then an approximate 140,000 hearing impaired children will be locked out of school.

In the report of the National committee on educational objectives and policies of (1996:74 Gachathi report), the committee noted that a basic problem on special education is the cost of special equipment the handicap must have. The Gachathi report (1976;77) noted that basic equipment (Perkins, Braille, tape recorder and type writer) for one blind student at 1976 prices would cost Ksh. 32,000. Taking twenty shillings to translate to one dollar in 1976 then, the cost today of the same gadget would be approximately Ksh. 224,000 given that one dollar today is equivalent to kshs70. With the economic constraints today, no one can think of purchasing such equipment. It is with these facts at hand that the researcher proposed to carry out a study on alternative internal financing of special institutions.

Special schools in Kenya have continued to operate under difficult circumstances with big pending bills and salary arrears to board of governors' employees amounting to US $\$ 0.24$ million (approximately Ksh.19 million) as of 1999 (MOEST 1999:20). This has forced the school in the past to undertake very primitive ways of soliciting funds 'begging in towns' so as to fund the co-curriculum activities. Having not exhausted fully all other avenues of generating funds, this can be termed as child abuse. The researcher believes that there is still more fields to venture into and save the situation. The rate and intensity of dependability can be minimized and eventually eradicated if we educate the nation. This will also witness the realization of an economically stable nation. It is evident that the government alone cannot adequately meet all the financial needs of the national education sector (Epari C.E 2004) hence the study sought to find out an alternative financing of special education.

\section{Theoretical Framework}

Wiersma (1985:13) confirmed that theories help to provide a framework by serving as the springboard for the pursuit of a research problem. They help to identify the crucial factors and provide a guide for systemizing and inter-relating the various facets of the research.

This research has employed the human capital theory which suggests that an "Investment in education increases Labour's productivity by embodying in the labour increased skills and knowledge" (Simon 1980:24). The policy implications of the theory includes the project that increased amount of schooling will increase their wages and reduce social inequality. The educational plan part of the 1964/65-1968/69 development plan was largely implemented in terms of enrolment targets. Secondary and higher education expanded to meet the countries estimated manpower requirements, and enrolment at the primary level increased at roughly the rate anticipated.

Investment in human resource is important in both raising the worth of the individual as well as creating skills that 
could be reaped in societal development. People acquire useful skills and knowledge which are a form of capital that is in substantial parts, a product of deliberate investment. This combined with other human investment account for the production superiority of the technically advanced countries (Schultz 1971:24; 28).

In relation to special education (Wood M. 1978) "the economics of special education in a developing country" (Lynch 1994:34) observes that any additional investment in special programmes is reimbursed to the community many times over through output and taxes, and that every dollar spent on special education the individual will earn eleven dollars as an adult. (Hammerman and Mackowski 1981:54) observe that apart from more apparent implication of disability for the people directly affected, disability has consequences for society as a whole. Disability results in a loss of national income and like other chronic social and medical problems, it may reduce the capacity of the individual to absorb education, to be productive at work, and to function independently. Disability can also place a heavy burden upon those who must care for the disabled, sometimes causing a reduction in the economic performance of the care providers. A loss in psychological well-being, while limiting the economic capacity of the disabled person, may also affect the economic productivity of his/her family and friends.

In order for a child who is less advantaged to acquire the necessary skills and knowledge, adequate resources, both public and private sector needs to be invested into their education as this is building national society which will reap back the benefits in form of society that is productive and less dependent on other.

\section{Research Methodology}

According to Borg and Gall (1996), a research design is a logical and valuable way of looking at the world. Orodho (2004) argues that a design should facilitate the research as efficient as possible in yielding maximum information. In this study the research has used a case study with a descriptive approach. Cohen and Manion (1992.123) ascertain that case study have a number of advantages that make them attractive to educational evaluators/researchers. Lovell and Lawson (1971: $29,41,41)$ continued to add that case study design seek to uncover the nature of the factors, degree in which they exist and discover the links/relationships which exist between the factors. They conclude by observing that the purpose of a case study is to examine the characteristics not of a large sample or a total population, but of an individual unit.

The researcher analyzed school records and documents to collaborate responses given in the questionnaire. Mwiria and Wamahiu (1995) describes document analysis as the best tool of accessing valid information since it can not create, waiver or withhold information. The researcher analyzed the records from the school. The information that was analyzed from the school includes; school expenditure, students and KCSE performance. All completed instruments were assembled and information organized. Quantitative data were analyzed using descriptive statistics with the help of a S.P.S.S programme and results on averages, and percentages presented through charts, graphs and tables. Qualitative data on the other hand, which were generated from the open ended questions, were organized into themes, categories and patterns pertinent to this study. As Mugenda et al (1999) observe, this entails creating a factual code which serves the purpose of identifying a fact of feeling or an attitude from the text. From this the researcher has to closely evaluate the usefulness of information in answering the research questions.

\section{The Review on Educational Funding}

Cowan (1968:106-107) on the costing of learning in Kenya revealed that the system of financing primary education by 1968 had virtually put the entire cost of primary education on the shoulders of the county and municipal councils. Fees and Graduated Personal Tax (G.P.T) were the main source of revenue for the council. He further stated that the municipalities with their more efficient tax collection and limited areas, together with the county councils were reaching a point where primary education was becoming a burden to them.

Education faces increasing constraint in both developed and developing countries as a result of economic pressures which have led to cuts in public expenditure and declining budgetary allocation for education. A prospective study on Sub-Sahara Africa, the World Bank $(1989: 2,81)$ summarizes Africa's economic conditions by observing that;"Africa's deepening crisis is characterized by weak agricultural growth, a decline in industrial output, poor export performance, shooting debts among others. Finance is considered as a significant element in the provision of education and consequently, its provision to finance education is paramount. However from different authors, journals and newspapers, there is a major problem that faces the school administration and planning. Campbell (1971) concurred that money is an important element for the success of any venture in any organization like education. 


\section{Review of Financing Special Education}

Financial support was found to be necessary for the effective running of schools. If funds were inadequate or unwisely expended, the schools would not realize their potentialities. One could not talk of schools and education without talking of how a school or an education programme was to be funded. Ozigi (1977) stated that no organization could survive or carry out its functions without adequate financial resources at its disposal. Johns and Morphet (1969) stated that every citizen should recognize that if every citizen were to be satisfactorily educated, it would be necessary to provided schools and other appropriate education institutions. Inter-Agency (1990), observes that educational inequalities in most countries are commonly related to poverty, gender, geographical location, religion, linguistic or ethical identification and physical and mental inability.

Hertley (1968) stated that schools had suffered because of problems in designing their programmes, assessing their performance and developing suitable locative means or strategies to determine how best to utilize limited human and non-human resources in the process of learning. The author further stated that school activities could be portrayed as a system which served to integrate curriculum planning and other components of an education programme with financial administration.

According to UN (1981) education is a self-sustaining process and to have a good supply of teachers tomorrow, a country must educate a good number of teacher trainees. According to Kamunge (1988) teachers trained for special education should teach in special schools in order to maximize utilization of the limited qualified manpower in the area. Sinyo (2002) advocates that disabled children should be encouraged and supported to display their talents because they can grow up to lead successful lives.

According to Parish and Chambers (1996:1) over the past twenty years, services for students with disabilities have become a major component of public education, in the USA by some estimates accounting for $12 \%$ of public school expenditure with the cost per student being at about 2.3 times the cost of regular education. About $8 \%$ of special education funds come from the federal government, $56 \%$ from the state government and the remainder from local school districts. It is estimated that USA used 31.8 billion or 12\% of 1995-1996 expenditure for special education nationally observed Parrish and Chambers $(1996,121,125)$. This is in contrast to the Kenya scenario where special education received Ksh. 54,049 million an equivalent of $0.10 \%$ of the Ministry of Education Science and Technology recurrent expenditure vote for 2001/2002 financial year (Republic of Kenya 2002:36).

In Jordan the ministry of social development is responsible for providing educational services for handicapped children through the department of special education. The state educational system provides $50 \%$ of the education services to the handicapped while vocational organizations meet the difference.

The government of Kuwait offers special education through the ministry of education under a network of special schools with the state education system providing $70 \%$ of the education services to the handicapped and $25 \%$ from other voluntary agencies. State provision of special education is financed by individual donation, (UNESCO 1988:68-73). The provision of special education in Pakistan rests with the Directorate of Special Education which gets funding from the federal government.

In Qatar the financing of special education and technical education is undertaken by the state (UNESCO 1996, 143-153). According to the Ministry of Education Science and Technology (1999:20) there are 107 fully fledged Special Schools and Institutions, although MOEST disburses recurrent grants to only 38 of them. The rest of the schools are provided for by the donors and religious organizations. The Ministry of Education further notes that in recent years, the private sector and the community have begun to make contributions directly to the schools in form of donations. Development expenditure by MOEST on special education is minimal and although most of the programmes are donor funded, sustainability has not been adequately addressed MOEST (1999:47).

The national development plan 2002-2008 Republic of Kenya (2002:58) observes that; "Out of the 1.8 million handicapped children of ages $0-19,55 \%(9,900)$ have been assessed and $22 \%(2,178)$ in both regular and special schools. This low enrolment has been caused by high cost of providing adequately trained teachers and other support personnel, specialized equipment and instructional material, appropriate physical facilities, medical services and poverty.

The master plan on education and training 1997-2010 (ROK 1998:26) pointed out that the handicapped are grossly under-enrolled in schools. This being the situation, the researcher is committed in trying to come up with findings that will enable such schools to generate extra finances so that the disadvantaged children are not denied access to education as it is the case today.

Karugu et al $(1995: 17,103)$ found out that grants to special education are always given without any objective criteria, probably resulting from the fact that there is no policy on the funding of special education as well as a formula on how these grants should be disbursed. The MPET recommended that the special needs of such children be taken into 
account in putting up school facilities (ROK 1998:62). The master plan further points out that in 1992/93 the expenditure on every 100 secondary school students would have financed 260 primary school pupils, while 100 university students cost the equivalent of 4,100 primary school pupils. In 1995/96, the government spent Ksh 87 on every pupil while it spent Ksh. 3,645 on every university student besides Ksh 773 from loans. For that same period of 1995/96, the cost of Kenya Institute of Special Education (KISE), were budgeted at twice the cost of a university student and ninety five times the cost of a primary school pupil. The 1992/93 expenditure on KISE was equivalent to the cost of nearly 15,000 primary pupils (ROK 1998:159-160). Karugu et al $(1995,105)$ showed that as of 1995, it cost the government Ksh. 171,405 to train a student at KISE every year. At a population of 120 it would cost the government large sums of money to sustain the programme. These statistics suggests that the resources in the education sector are not being prudently allocated; at KISE trainees together with university students seem to get large sums for their training at the expense of the disadvantaged students/pupils in the society.

It is worth noting that for every US \$ invested in the physical and cognitive development of infants and young children, there is US $\$ 7$ in return, mainly from future savings on costs such as healthcare, remedial education, unemployment and crime 1998 study by the Rand Corporation Parrish and Chambers (1990).

Okello (1996:45-63) found out that funds for St. Catherine Special school for the mentally handicapped came from fund raising, government, donors, Catholic missions' funds solicited from overseas sponsors and parents who pay some minimal boarding charges. Similarly, in Rev. Muhoro school for the deaf the funds comes from the parents, sponsors, (the P.C.E.A church and individuals who sponsor some students) donors, government and at times windfalls. This situation has triggered the researcher's mind that there are several and potential ventures for income-generating activities in these special institutions that can be exploited to fund part of their education. In a study on cost and financing of special education in Kenya, Karugu et al (1995:9) suggests that "It will be necessary to expand expenditure on special education so as to achieve accessibility, equity and quality. This can be done through reallocation of existing resources, encouraging the establishment of other sources of revenue and reducing unit cost by improving the efficiency of the special education programmes such as integration. This is generally less expensive than running segregated institutions and with proper planning, with all resources provided, would enhance accessibility, equity and quality of learning for the disabled.

\section{Need For a Subsidiary Funds to Supplement School Budget}

The World Bank's experience of education investment, in Psacharopoulos and Woodhall (1985) is that education fulfils a number of vital objectives, in other words; the need for adequate planning and financing of educational investment arises from the fact that education fulfils very important goals. Schulz (1961) and Denison (1962) showed that education contributes to the growth of the national income by improving the skills and productive capacities of the labour. Hicks and Wheeler (1980) reaffirmed the importance of education in promoting economic growth.

Opportunities to education are viewed under the same base, this disregard the recipient of education. The aftermath of education whether to a hearing impaired or hearing student is the same. The research would want to shed light that disability is not inability. The education curriculum followed in all secondary schools in the Republic of Kenya is the same as that being used by the hearing impaired institutions. Thus, any educational planning, financing, management etc implemented in the public and private secondary school also affects the hearing impaired institution in the same weight. Planning for educational financing can be borrowed from financing of primary education, secondary education or special education.

The Kenya education commission (1965:109) reported that there was no form of tax that was known to the ministry of local government by 1965 which was capable of supplying the revenue of local authorities in substitution for school fees. Whereas the commission's attention was directed upon the community's participation, it however remarked that the substitution of communal for parental responsibility calls for a psychological change in the community that cannot be encompassed overnight for it involved the suppression of the family or clan by the country which is the main object of loyalty.

As a result of the rapid expansion of the education sector, pressure on government budget on education has increased. At the national level, recurrent government spending on education has been higher than any other social sector spending -73 percent of the social sector expenditure (see Figure 2 below). 
Source: Economic Survey 2004

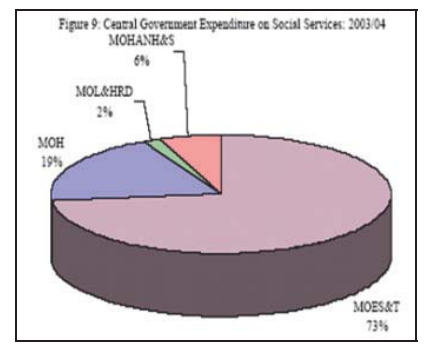

Taking 1978/79 as our financial year of reference, the percentage of the government's total recurrent expenditure that goes to the financing of education has continued to rise from $25.6 \%$ in $1978 / 79$ financial year to $37.2 \%$ in $1987 / 88$ financial year. Between 1984/85 and 1987/88 financial year there was a steady rise of 7\% of the recurrent expenditure Kiuni, R.K. (1990). Since 1975, very little success has been achieved in curbing education spending. In addition, Education's recurrent budget has risen from 35 percent of public sector recurrent budget in 2000 rose to 39 percent in 2004, with about 79 percent going towards, administration and planning, as shown in Figure 2 below. Out of 79 percent, 86 percent goes towards salaries and wages. Furthermore, out of the total allocation to the MOES\&T, 50 percent of the resources go to primary Education, with about 85 percent of the fiscal resources to primary schools being used to pay teacher's salaries. Also, development expenditure has increased since 2003 as a result of the implementation of the FPE leaving little allocation to other sub-sectors as indicated in Figure 3 below.

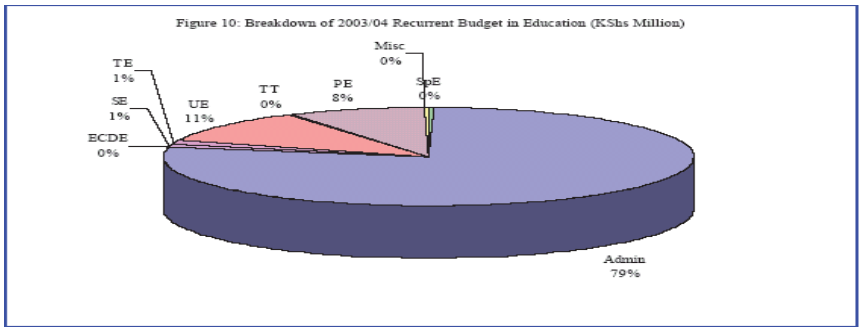

Source: Economic Survey 2004

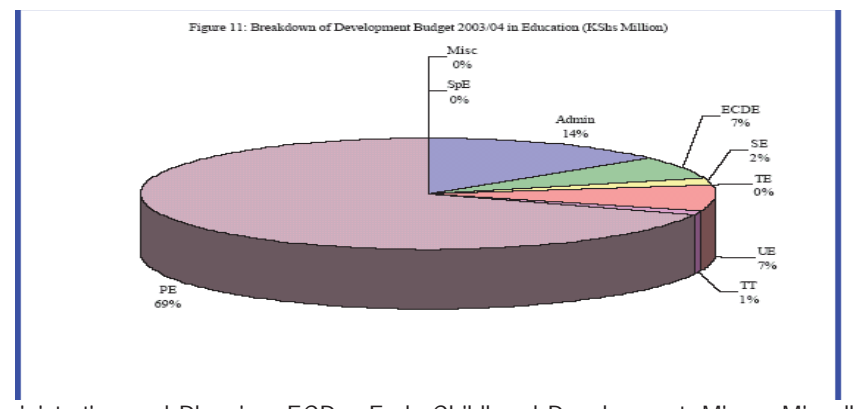

Where Admin - Administration and Planning, ECD - Early Childhood Development, Misc - Miscellaneous, PE - Primary Education, SE -secondary education,-TE tertiary education, UE-university education, TT-technical training

Source: Economic Survey 2004

Various decisions, example Abolishing school fees and school milk and feeding programme, has ran contrary to the intention stated in 1975 sessional paper and in the 1974/78 and 1979/83 development plan whereby the government had intentions of reducing the annual growth rate of education expenditure to less than $11 \%$ by the end of the plan period, compared to $15 \%$ at the beginning. The target was not realized as education spending continued to escalate. Eleven years down the line the government once again felt the need to curb the escalating educational spending. Sessional 
paper No.1 of 1986 on "Economic management for renewed growth" states that the government decision is to reduce the recurrent expenditure on formal education and training under the Ministry of education to about $30 \%$. The success of this intention is still far from reach. Four years after the date of the paper, the then minister of education Aringo 0 . on education spending, (Oct, 9th 1989: 3) commented that; "education continued to take a big share of the national budget which stood at $38 \%$ in 1988/89 financial year."

According to the economic survey (1982.116), it was stated that the government has given priority to the policy of encouraging viable interaction between schools and local communities particularly parents' associations. Families have since then been financing educational development in Kenya for a long time. Since the advent of "Harambee" movement in the early 1960s, many educational facilities have been developed. Olembo (1985) has noted that the establishment of Harambee secondary schools and subsequent introduction of Harambee streams in the government maintained secondary schools has to some extent saved the government from the pressure of investing in the secondary education sector. The self-help efforts (Harambee) of financing education have been acknowledged by Psacharopoulos and Woodhall (1983), Mingat and Tan (1984), Mingat and Psacharopoulos (1984) on the bases of efficiency and equity considerations.

In the 1984-1988 development plans, the government clearly advocated for "cost-sharing" policy with those who benefit from its services. The International Institute for Education Planning (I.I.E.P), a strong arm of the United Nations Scientific and Cultural Organization (UNESCO) has launched research project into financing educational systems in various parts of the world. It noted that research into financed education system has a broader aim not only of looking at the real possibility of the developing countries financing their educational objectives but rather to study the various financing methods likely to augment resources and to define a strategy of educational financing more closely adopted to social and economic realities. World Bank (1980) appreciated the need for additional sources of financing education.

As early as 1961, the United Nations Educational scientific and Cultural Organization (UNESCO) in an apparent anticipation for future global educational expansions suggested that an increase in national education budget requires an increase in financial resources both in public and private sectors Psacharopoulos (1990). Kelly (1991) suggests that this can take the form of introducing schemes, whereby educational institutions can generate their own funds.

The Government of Kenya commitment to implementing the Structural Adjustment Policy package, recommended by the International Monetary Fund (I.M.F) and the World Bank was enunciated in sessional paper No.1 of 1986 on "Economic management for renewed growth" and sessional paper No. 6 of 1988 on "Education training to the next decade and Beyond"(Republic of Kenya 1986/1988). This provides the long term framework within which the next three five year's development plans would be formulated. Beginning with the 1989-1993 development plans it was to introduce cost-sharing arrangement in a number of service sectors, including education so as to increase government revenue generated from users of services and reduce budgetary deficit Odada and Odhiambo (1989), G .O. K, UNICEF, (1995). A World Bank (1986) study on financing education in developing countries noted that cost-recovery measures would generate substantial revenue without reducing enrolments. Rono (1988) agreed with cost-sharing as the only viable solution to easing the burden of financing education on the government exchequer.

According to presidential working party report on education and manpower training, the government continues to finance the cost of general administration and professional services which constituted a major item on the education recurrent expenditure (R. O. K and UNICEF 1999). Such high level of recurrent expenditure on education were seen by the government as unsustainable and meriting reduction or at least control. It is with this fact, that the World Bank (1988) advised Kenya among other countries, to institute cost-sharing scheme and to reduce government expenditure. The idea was that people should pay for what they consume and the private and public sectors should be left to do the things they can perfect, while the beneficiaries, the local communities and sponsors provided facilities in all other educational and training institutions. Students in the public institutions were to provide the full cost of boarding and feeding.

\section{Subsidiary Sources of Funds}

Coombs and Halleck (1972) maintained that in order to give sound guidance to policy makers, educational planners had to be able to make reasonably accurate forecasts of future educational costs as well as resources needed and resources likely to be available. They should also design/develop plans that are achievable and marketable. Inflation is an obstacle the educational planners have to contend with. Miller and Spalding (1958) stated that fluctuation of prices and uncertainty with respect to programme and personnel made it difficult to develop an exactly accurate set of expenditure estimates. The author felt that even when the budget was as sound as possible, reasonable allowance had to be made for fluctuation over which the administrator had no control. Horstman (1967) in an article; financing education in England; stated that some heads spend money immediately in order to get maximum use of supplies and avoid the possibilities of 
rising costs. Even when this might have appeared as a solution, the author felt it has its problems especially if the goods to be purchased were of a perishable kind. The programme of education placed a tremendous responsibility on the available administrative practices and resources. These had to be improved and designed to meet the many problems of planning, plan implementation, educational leadership etc that were inherent in the rapid expansion of the school. Raju (1973) and Knezevich (1975) stated that administration helped to assemble and ensure prudent use of resources. The author considered the administrators to be the basic source and perhaps the most precious resource in an enterprise.

To exploit these opportunities the public service institutions have to become innovative and enterprising. .Hamilton and Williams (1986) noted that funds for the smooth running of educational programmes is raised through the organization of events such as fairs, goods sales, crafts etc. Some schools sold items from their agricultural, home economics, industrial arts and craft department. Study by Ogbu and Gallagher (1991:312) revealed that; "School in Ethiopia used their resources intensively in financing of education. Many of the schools produce their own teaching aids as well as some crafts and garden crops for local sale. Schools use internally generated resources to supplement government and community effort."

Nayar and Varmanis (1978) observed that secondary school students in India's Tamil state have been mobilized to help nearby primary school children in "godfather" scheme. The help mainly takes the form of labour and books. Parallel activities have been achieved through the "school cluster" project in Sri Lanka. Damarayake (1985), Kastakov, Brace and Murvil (1978) notes that on the Burris high school of Philippines, production is made part of the broader curriculum and mechanism through which pupils could pay their fees.

Mahatma Gandhi's famous experiment in India that if children worked for three hours in a day, a class of thirty children could raise enough money to pay for their teacher's salary and still have something over for contingencies. Nafukho (1990) suggested that where conditions are favourable Kenyan secondary schools should be encouraged to engage themselves in some income-generating activities. Kipkulei and Gravenir (1991) agreed with Nafukho by appealing to schools to start income-generating projects to supplement funds by the government.

Drucker (1986) concludes that the public service institutions need clear definitions of their mission, realistic statement of goals in optimal rather than maximal terms and should build into their policies and practice the constant search for innovative opportunity. Brooksbank (1980) argued that since instructional service was the most important item in school work, a large percentage of school funds as possible has to be given to it without taking money from other services which could result in the crippling of the institution. Hence Van Dosseldrop (1971) states that available resources and opportunities had to be efficiently utilized to supplement the existing finances. A living testimony is that of the ST. Mary's Secondary school in Nyeri where the students are assigned duties at least once in their school life time. During this one day-off the students are supposed to look after the daily cows in the school compound and this include milking. Another good example is the Kandara children home in Maragua district, where those children grows trees seedlings, cabbages, kales and later sell the products either directly to the school or to the community. The money that they get from the sales goes to their school fees and daily up-keep. The institution has other income-generating projects like the daily cows and rabbit keeping. Generally in both instances the money that would have been used to cater for the salaries and other expenses is transferred to subsidising other vote heads.

\section{Data Presentation, Analysis and Interpretations}

\subsection{Demographic Characteristics of Respondents}

This study sought views from 34 respondents with a wide range of demographic characteristics. These characteristics are summarized and presented in this section.

\subsubsection{Age of Students}

Table 4.1 presents the distribution of students according to age.

Source: researcher

\begin{tabular}{|c|c|c|}
\hline Age & Frequency & Percent \\
\hline 15-17 years & 9 & 30.0 \\
\hline 18-20 years & 15 & 50.0 \\
\hline 21 years and above & 6 & 20.0 \\
\hline Total & 30 & 100.0 \\
\hline
\end{tabular}


Figure 4.1: Distribution of the students according age

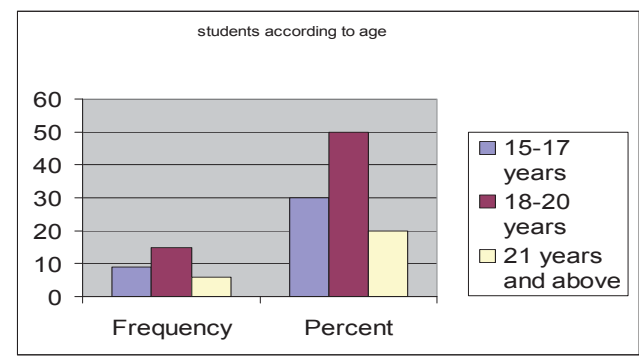

The results show that most of the students (50.0\%) are aged between 18 to 20 years.

\subsubsection{Gender of the Students}

Table 4.2 presents the results on gender of the sampled students.

\begin{tabular}{|c|c|c|}
\hline Gender & Frequency & Percent \\
\hline Male & 15 & 50.0 \\
\hline Female & 15 & 50.0 \\
\hline Total & 30 & 100.0 \\
\hline
\end{tabular}

Source: researcher

Figure 4.2: distribution of the students according to gender

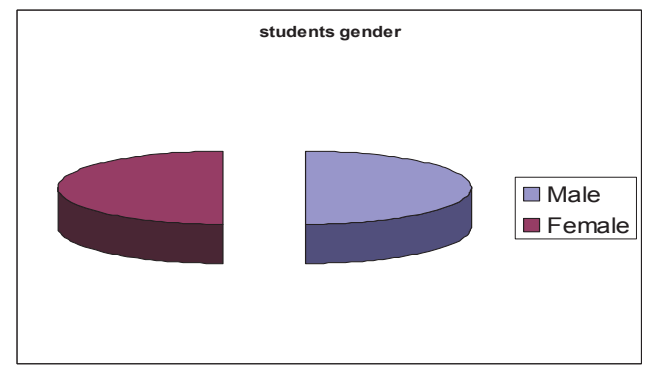

The data in Table 4.2 and Figure 4.2 indicate that sampling yielded equal number of male and female students (50.0\%).

\subsubsection{Class of the Sampled Students}

Table 4.3 presents the results on the distribution of the sampled students according to their classes.

Table 4.3: Distribution of the Students According to Class

\begin{tabular}{|c|c|c|}
\hline Class & Frequency & Percent \\
\hline Form Four & 15 & 50.0 \\
\hline Form Three & 9 & 30.0 \\
\hline Form Two & 6 & 20.0 \\
\hline Total & 30 & 100.0 \\
\hline
\end{tabular}

Source: researcher 
Figure 4.3: distribution of students according to classes

\section{Source: researcher}

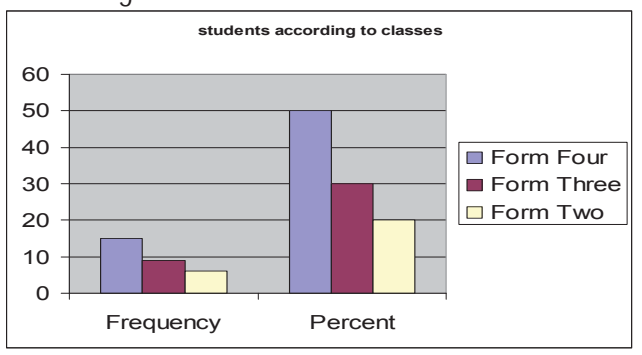

The results in table 4.3 and figure 4.3 show that most of the students were drawn from form four classes (50.0\%).

\subsubsection{Parents Level of Education}

Table 4.4 presents the results on the sampled students' parents' level of education.

\begin{tabular}{|c|c|c|}
\hline Parents' level of education & Frequency & Percent \\
\hline Non literate & 6 & 20.0 \\
\hline Primary level & 18 & 60.0 \\
\hline Secondary level & 3 & 10.0 \\
\hline Tertiary level & 3 & 10.0 \\
\hline Total & 30 & 100.0 \\
\hline
\end{tabular}

Figure 4.4: Parents level of education

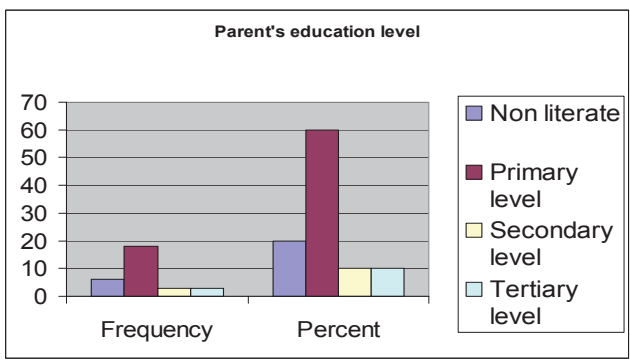

Source: researcher

The results in table 4.4 show that most students had parents with primary level of education. None had a parent with university level of education.

\subsubsection{Occupation of Students' Parents}

The findings on the sampled students' parents' occupation is presented in table 4.6.

Table 4.5: Occupation of Parents

\begin{tabular}{|l|c|c|}
\hline \multicolumn{1}{|c|}{ Occupation of parents } & Frequency & Percent \\
\hline Self employment & 9 & 30.0 \\
\hline Casual worker & 9 & 30.0 \\
\hline Subsistence farmer & 9 & 30.0 \\
\hline Small scale commercial farmer & 3 & 10.0 \\
\hline \multicolumn{1}{|c|}{ Total } & 30 & 100.0 \\
\hline
\end{tabular}

Source: researcher 
Figure 4.5: Occupation of parents

\section{Source: researcher}

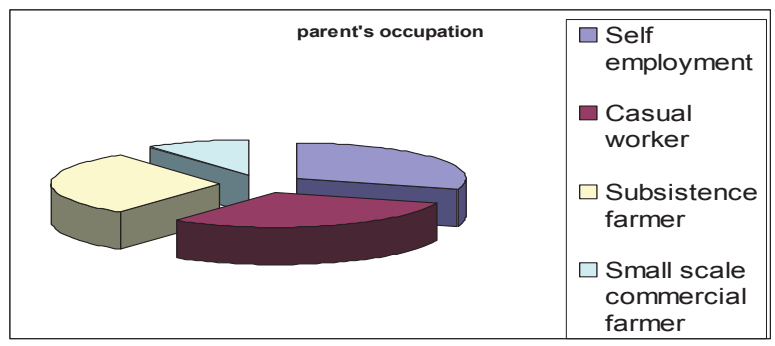

The results in table 4.5 and figure 4.5 show that majority of the students had parents who are either self-employed (30.0\%), subsistence farmer (30.0\%) or casual worker (30.0\%).

\subsubsection{Students' Enrolment Trend}

The results on the students' enrolment trend in the past five years are presented in Figure

Figure 4.6: Students' Enrolment Trend in the Past Four Years

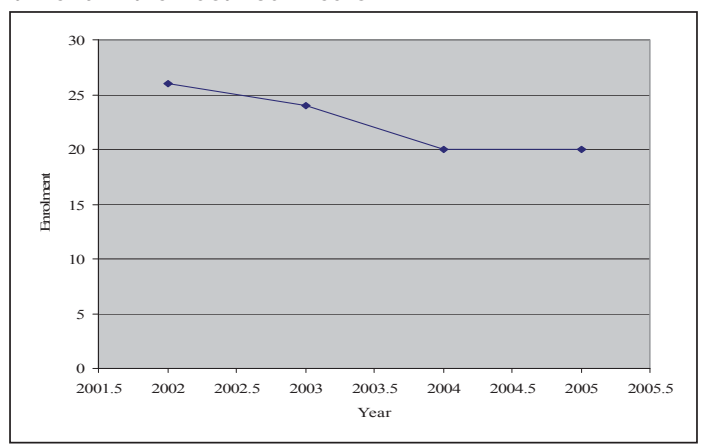

Source: researcher

The trends observed in looking at Figure 4.6 show that the enrolment has been on a down ward trend since 2001 . According to the principal, dropout and absenteeism has also been on the increase. This he attributed to mainly lack of school fees, a factor that was confirmed by the students as well.

\subsubsection{Performance in the KCSE Exams}

The results on the institution's performance in the KCSE exams in the past four years are presented in Figure 4.7 below.

Figure 4.7: Performance in the KCSE Exams in the Past Four Years

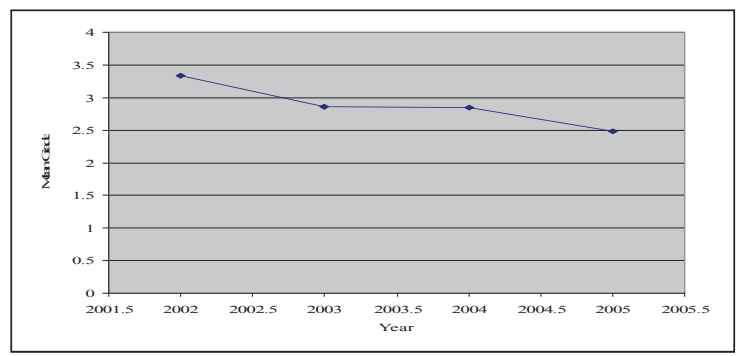

Source: researcher 
According to the results in Figure 4.7, the performance in the KCSE has been on the down ward trend in the past four years.

\subsection{How the institution is financed}

This section presents the results of the findings on how the institution is financed.

\subsubsection{Source of finance}

The principal was asked to identify sources of finance for the institution and the percentage of the finance. The results are presented in Table 4.7.

Table 4.6: Sources of Finance

\begin{tabular}{|c|c|}
\hline Sources & Percentage \\
\hline Government & 25 \\
\hline Well wishers & 5 \\
\hline Parents & 50 \\
\hline School itself & 20 \\
\hline Total & 100 \\
\hline
\end{tabular}

Source: researcher

Figure 4.8: sources of finance

Source: researcher

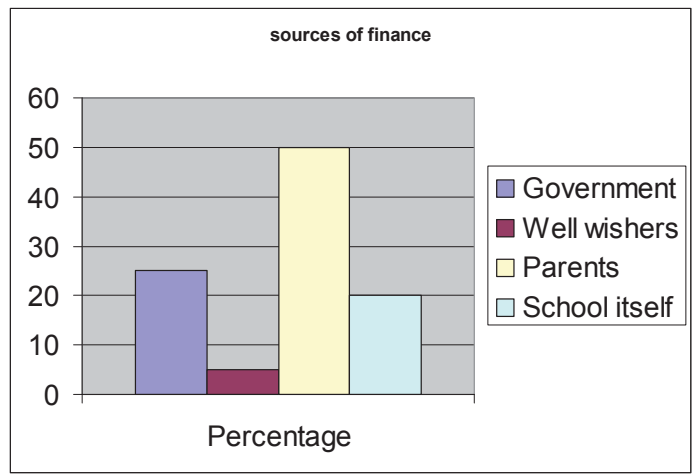

According to the results in Table 4.6 and figure 4.8, the institution is financed by the parents, Government, school and well wishers. The main financier according to the principal is the parents (50.0\%). The second ranked financier is the government at $25.5 \%$. The least financier is well wishers (5.0\%). An interview with the PTA chairman revealed that in terms of finance, the PTA chairperson assist in enlightening the parents on the essence of paying school fees, assist in organizing Harambee to raise finance and its committee oversees the income-generating projects in the school.

According to the principal, the current resources are not sufficient for recurrent expenditure. This has interfered with the effective running of educational programmes in the school. These programmes include the fact that; the school cannot be able to organize education seminars, trips, and symposium. The school is unable to purchase adequate instructional material and to construct enough classes.

\subsubsection{Institution's Assets and Their Adequacy}

The study sought to establish the institutions' main assets and to further find out whether they are adequate in meeting the institution's objective of providing education to the handicapped children in the society. According to the principal and the PTA chairperson the school has a total of 8 acres of land. The other assets include computers, printers, scanners, CD 
writers, TV, video camera, radio, ear equipments, water pump and sewing machines. Among these assets according to the principal, classrooms and the computer rooms were insufficient. It was only the special room for the ear clinic that was sufficient. The study also found that the institution lacked a bus/van, laboratories, home science room, workshop and a dinning hall. This according to the principal was due to lack of funds to finance these projects. The researcher also sought to find out from the students how inadequacy or absence of these facilities affects them. The results of their responses are presented in Table 4.7.

Table 4.7: Effects of the Inadequacy or Absence of Educational Facilities on Students

\begin{tabular}{|l|c|c|}
\hline \multicolumn{1}{|c|}{ Effect } & Frequency & Percent \\
\hline Poor performance & 11 & 36.7 \\
\hline Lack of practical in sciences & 17 & 56.7 \\
\hline Waste of time Total & 2 & 6.6 \\
\hline \multicolumn{1}{|c|}{30} & 100.0 \\
\hline
\end{tabular}

Source: researcher

Figure 4.9: Effects of the inadequacy of educational facilities on students

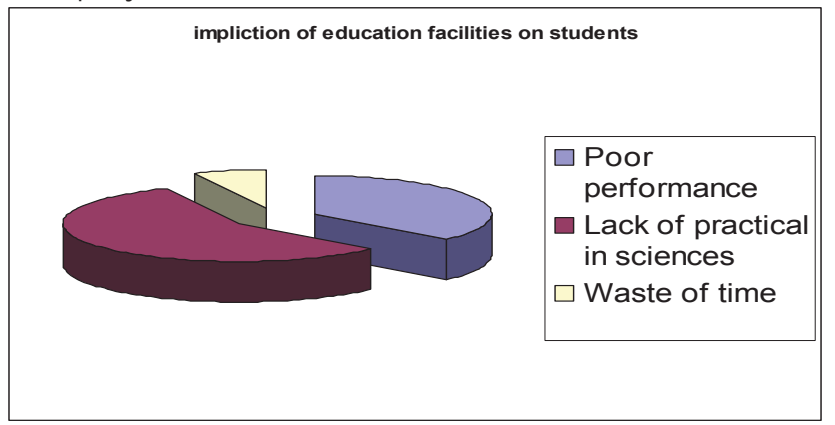

Source: researcher

The results in Table 4.7 and figure 4.9 show that the absence of facilities such as laboratories, workshop and science room leads to first and foremost lack of experiments (56.7\%) and in the final analysis poor performance (36.7\%). It also contributes to waste of time (6.6\%). The students were further asked to identify which among the facilities they would like to be provided immediately. The results of the findings are presented in Table 4.8.

Table 4.8: Priority Educational Facility that should be provided

\begin{tabular}{|l|c|c|}
\hline \multicolumn{1}{|c|}{ Facility } & Frequency & Percent \\
\hline Equipped Laboratory & 24 & 80.0 \\
\hline Classroom & 3 & 10.0 \\
\hline Dormitories & 0 & 0.0 \\
\hline Computer laboratory & 0 & 0.0 \\
\hline Home science room & 0 & 0.0 \\
\hline Resource centre & 1 & 3.3 \\
\hline Text books Total & 2 & 6.7 \\
\hline \multicolumn{1}{|c|}{ Tom } & 30 & 100.0 \\
\hline
\end{tabular}

The results in Table 4.8 indicate that the top ranked priority for the students is for a well-equipped laboratory to be provided (80.0\%). The main reason sighted for this is that they would want to do more practical in science subjects. They also stated that with a well-equipped laboratory they would be able to perform better than presently. With regard to textbooks, the students stated that with the current shortage they are unable to carry out effective private studies and do assignments.

An attempt was also made to find out from the students the alternatives used by the school in the face of inadequate or lack of educational facilities. The results of the findings are presented in Table 4.9. 
Table 4.9: Alternatives for Inadequacy or Absence of Educational Facilities

\begin{tabular}{|l|l|}
\hline Facility & Alternative \\
\hline Laboratory & Classroom \\
\hline Dormitory & Sharing \\
\hline Workshop & Classroom \\
\hline Home science room & Classroom \\
\hline Furniture & Sharing \\
\hline
\end{tabular}

The results in Table 4.9 reveal that in the absence of laboratory, workshop, and home science room, classrooms are used as the alternative. However, inadequacy in the dormitory and furniture forces the students to share. It was also necessary to find out if the students find the alternatives used by the institution appropriate. The results of the findings are presented in Table 4.10.

Table 4.10: Are the Alternatives for Inadequacy or Absence of Educational Facilities Appropriate

\begin{tabular}{|c|c|c|}
\hline Appropriate & Frequency & Percent \\
\hline Yes & 6 & 20.0 \\
\hline No & 24 & 80.0 \\
\hline Total & 30 & 100.0 \\
\hline
\end{tabular}

The results in Table 4.11 show that the improvisation utilized by the institution for the inadequacy of the missing facilities was not appropriate according to the majority of the students (80.0\%). They would rather have these facilities provided.

\subsubsection{Challenges Encountered by the Institution on Planning for the Allocated Finances}

This section presents the results of the findings on the challenges encountered by the institution's administration on planning for the allocated finances. As reported previously, the principal reported that the finances available in the institution are not sufficient to provide the necessary educational facilities needed for the smooth operation of the institution. Among the challenges identified by the principal arising from this shortfall are failure to avail adequate learning and teaching materials such as textbooks, inability to organize educational trips, seminars and symposiums, lack of capacity to construct well equipped laboratories and workshops.

According to the institution's accounts clerk, they are at times forced to operate in debt especially at the end of the year when the accounts are low and they are under the obligation to pay the subordinate staff and run other school programmes like purchasing chemicals for experiments in the KCSE exams. The PTA chairman decried the poor payment of fees by parents who can hardly afford to meet their obligations as a big hindrance to providing the critical educational facilities needed for the smooth running of the institution. He pointed out that although bursaries are provided to needy students, since most them come from a poor background, the amount provided is hardly enough. Most parents pay fees in piecemeal. This at times disorientates the budget especially where the market price of a particular product has changed from the time of budgeting. The principal described fee payment by parents as poor.

\subsubsection{Alternative Sources of Finance for the Institution}

According to the principal and the PTA chairman the institution has 8 acres of land. Apart from the general purpose for which the land is put into use such as buildings and play ground, the land is utilized for farming, an activity that earns the institution extra income. The main farming activities undertaken on the land as confirmed by the observation schedule are pig rearing, dairy farming and coffee growing. The pigs and dairy products were mainly consumed in the school and subsidized money spent on food, while coffee was sold to earn extra income to the institution. However, according to the principal and the PTA chairperson, these were not enough to off-set the deficit that the institution has to enable its smooth operation.

The other assets used by the institution to generate income were renting of the buildings, offering computer services and providing accommodation facilities to church groups. However, each of these was reported by the principal to earn less than Ksh. 10,000 per year. The other alternative source of finance according to the PTA chairperson is fundraising drives that are held annually. These funds drive have been realizing between Ksh. 70,000 to 100,000 
annually since the year 2000. However, according to the PTA chairperson, the most limiting factors on relying on funds drive are, lack of money to contribute, organizational problems and community's ignorance on the benefits of such drives.

\subsubsection{Finance and Performance}

According to the institution's principal the enrolment in the school is high. However, the rate of survival is $75.0 \%$. The main reason for this is that majority of the students transfer to other schools. Others drop out due to lack of school fees. As was presented earlier in this research, the enrolment trend is on a downward trend. The general performance of the school is described as fair, a performance that is below the potential of the school according to the principal. The mean performance is generally on a downward trend just like enrolment (Figure 4.2). The main reason attributed to this was the students' characteristics and lack of adequate facilities that is brought about by financial difficulties. The servicing of the school fees was described as poor by the principal. This is mainly attributed to rampant poverty. To the principal therefore, the poor financial status of the school has directly contributed to its low performance in National Examinations.

The document earmarked for scrutiny were receipt books, cash books, fees registers, commitment registers, store ledgers, inventory books, local purchase orders, local service orders, and general ledgers. However, the researcher was denied the access to these important but sensitive documents. The researcher was treated with a lot of suspicion and mistrust, to an extent that the school management thought that the researcher was there with a sinister motive

\section{Conclusion}

This study was designed to explore the subsidiary sources of funds to minimize financial constraints on school budget. The findings show that:

* The main source of finance for the institution is the fee paid by parents.

* The finance provided by parents and the government is not sufficient to enable the institution operate efficiently.

* The alternative sources of finance for the school are income-generating activities such as dairy, pig and coffee farming. The institution also hires out buildings to raise additional income and at times render computer classes at a fee. However, the income generated from theses projects are not adequate.

* The inadequate finance at the disposal of the institution has contributed to poor performance as the institute is not able to provide adequate educational facilities to the students.

* There is need to initiate more income-generation activities such as poultry and vegetable farming as well as water project to raise additional income to the institution.

* The government and other stakeholders should step in and increase their funding as well as assist in initiating income generating activities to enable the institution operate efficiently.

\section{References}

Achola, P. W 1988; "Mobilising Additional funds for Secondary and Higher Education in Kenya" Kenya Journal of Education Vol.4

Achola, P. W (1988); Mobilizing additional funds for secondary and higher education Kenya journal of education, 4 [1]

Anderson, J. (1969); "Harambee school: The impact of self-help" In jolly R (ed) Education in Africa: Research and Action: East Africa Publishing House, Nairobi.

Ayodo, T. M. (1989); Educational financing in Kenya; Practices and issues since the Ominde commission unpublished seminar paper. Kenyatta University.

Best, J. W. and Kahn, J. W. (2001); Research in education. New Delhi Prentice Hall of India.

Blang, M. (1968); The rate of returns on investment in Blang M (ed) Economics of Educational, selected readings, Suffolk.

Borg, W. R. (1998); Applying educational research, a guide for teachers, London

Bray, M. and Lillis, K. (EDS) 1988; Community financing of Education; Issue and policy implication in less developed countries. Pargamon Books Limited, London.

Campbell, R. (1971); Introduction of Education administration, Allyn and Bacon Inc, Boston.

Coembo, P. and Hallack (1972) Managing education costs IIEP, Paris.

Cohen, L. and Manion, L. $(1980,1989)$ Research methods in education Croom; Helm Ltd New York; Research method in education

Cowan, L. Gray. The cost of learning; the politics of Primary Education in Kenya. New York, Teachers College Press.

Drucker, Peter F. Innovation and entrepreneurship Pan Books Ltd, 6: London.

Eicher, J. C. Educational costing and financing in developing countries "Focusing Sub-Sahara Africa"; Washington, World Bank staff working Papers, No. 655

Fraenkel, J. R. and Wallen, N. E. (1993) How to design and evaluate research design in education McGraw - Hill, Inc 
Gall, M. D. Borg, W. R. and Gall, (1996) Educational research, New York; Longman Publishers

Gay, L. R. (1992); Education research, complements for analysis and application Macmillan publishing company, New York

Good, C. V. (1992); Essentials of educational research; methodology and design; New York, Meredith Corporation

Gravenir, F. Q. (1991); "An assessment of trends in Public financing of education in Kenya" Kenya journal of education vol. 1-5

Johnson, A. K. (1991); Education and economic crisis study of Mozambique and Zambia 1975-85 Washington DC World Bank

Karl, A. et al (1972); Resource Allocation in Non Market System; Baltimore and London

Keller, E. (1975); The role of self help school in education for development; The harambee movement in Kenya; Bureau of educational research, Kenyatta University College paper P 11-30

Kiiru, M. (1991); Practical ways of fund raising in Africa. In the Christian media,Vol. 2 No.1 A communication research and News journal, published by fellowship of Christian communication in Africa and Madagascar (F.O.C.C.A.M.) Nairobi, 14-21.

Kotter, P. (1987); Strategic Marketing for non profit organization. Cases and readings $3^{\text {rd }}$ Edition, Prentice-Hall, Inc Englewood cliffe, New Jersey Kothari, C.R. (1985); Research methodology, New Delhi, Willy Eastern Ltd

Lewis, I. K. and Caillods, F. (2001); Financing secondary education in developing countries; strategies for sustainable growth, Paris UNESCO

Lillis, K. and Ayot, H. (1988); Community financing of education in Kenya, In Bray, M. Lissis K. (eds) Community

Listokin, D. (1974) Education financing reform, New Jersey, Ratqer University.

Makau, B. M. (1987); The management and the financing of secondary education in Kenya; The effectiveness of policy at the school level. Unpublished report, University of Nairobi, Institute of development studies August

Mingat, A. and Lee Peng (1985); Subsidization of high education versus expansion of primary enrolment. What a shift of resources achieve in Sub-Saharan Africa. International journal of education development vol. 5 No 4

Mingat, A. and Lee Peng (1985); Educational cost and financing in Africa, some facts and possible lines of action. Washington DC World Bank discussion Paper, March 1987

Mohika, G. M. (1999) Financing of Public school and the provision of educationa facilities under 8-4-4 system of education in Bungoma division Nyamira District MRD, Thesis Kenyatta University

Morphet, E. and John, R. (1960); Financing the public school, Prentice Hall Inc New Jersey

Mugenda, O. M. and Mugenda (1999); Research methods, Qualitative and quantitative approaches. Acts press, Nairobi

Mutungi, O. Why millions cannot access education, Nairobi, Kenya times 31st July 2001; 14 col. 4-5

Muya, W. (1989); Nose tightens on education (excerpts) Sunday Natio Nairobi $9^{\text {th }}$ April

Mwiria, K. (1985); The Kenya Harambee School Movement; a historical Perspective; PhD dissertation Stanford University

Naya, D. and Varmani, K. (1988); Management of local support of education in India. A case study; Nation Staff College for educational Planners and administrative, New Delhi

Noor Mohamed, S. O. (1989); Recurrent expenditure on education in Kenya; An exploratory study, unpublished report, Nairobi IDRC July

Ogbu, O. M. (1991); On public expenditure and delivery of education in sub-Sahara Africa Comparative education review vol. 35 No. 2 May 295-318

Olembo, J. O. (1985); Financing secondary school education in Kenya, Kenyatta University, Bureau of education research

Orodho, J. A. (2004); Elements of education and social science research methods Masola publishers, Nairobi

Orodho, J. A. (2004); Techniques of writing a proposal and reports, Nairobi

Philip, H. et al (1972); Educational costing in action Paris

Psacharapoulos, G. Why education policies can fail. An overview of Selected African experiences, Washington DC

Reifman Lucille, (Ed) (1964); Financing of education for economic growth, Paris OECD

Republic of Kenya, Sessional Paper No 1 of 1965 on African socialism and its application to planning in Kenya, Nairobi Government Printer 1965

Republic of Kenya, Sessional Paper No 1 of 1986 in economic management for renewal growth, Government printers 1986 Nairobi

Republic of Kenya, Sessional Paper No 6 of 1988 on education and manpower training for the next decade and beyond, Government Printers, 1988, Nairobi

Republic of Kenya, Economic survey 1988 Nairobi Government Printer 1989

Republic of Kenya, Development plan for the period 1989 - 1993 Nairobi Government printer 1988

Ruju, N. B. (1973); Education in Kenya; problems and perspectives in educational Planning and administration. Heinman, Nairobi.

Singleton, P.A. (1993); Approaches to social research, Oxford University Press, New York

Slavin, R. (1984); Research methods in Education; A practical guide, Prentice Hall Inc New York

UNESCO, (1985); Education cost and financing, Paris UNESCO

Vassey, J. (1985); The economics of education, London Faber and Faber co.

Wanjau, K. K. (1990); Financing Management in Kenyan Secondary School; Problems and Issues MED Thesis Kenyatta University

Wesonga, D. M. (1996); Supplementary sources of funds for secondary education in Kenya. A survey of Kakamega District,

MED Thesis Kenyatta University

Wheeler, A.C.R. (1968); The organization of educational planning in Nigeria Paris

Wheeler, D. (1980); Human resource development and economic growth in developing countries; A simultaneous model

Wierma, W. (1985); Research methods in education, an introduction $3^{\text {rd }}$ Edition, London Allyn and Bacon Inc

World Bank; (1989); Sub Saharan Africa: From crisis to sustainable growth, a long term perspective study Washington DC 
World Bank (1980 -1983); Education sector policy paper Washington DC 